\title{
RESPONSE OF AWASSI EWES TO EXOGENOUS HORMONAL TREATMENT DURING THE REPRODUCTION SEASON
}

\author{
A.G. Ghadri \\ Department of Animal Production, Faculty of Agriculture, Aleppo University, \\ Aleppo, Syria
}

\section{SUMMARY}

This research was carried out using (40) Awassi ewes to investigate the effect of exogenous hormonal treatment on estrous synchronization and twining rate. The study was carried on during July 1999. All ewes were impregnated with vaginal sponges (MAP) for (14) days, and injected with about 330 I.U. (PMSG) at sponges withdrawal. The ewes were then divided into (4) similar groups, each was joined with adult fertile ram. Rams were changed every other day between groups until the cease of estrous manifestation, when they were replaced by a vasectomised ram to record the return to estrous. Data of lambing, pregnancy length, type of birth and sex of lambs and birth weights were statistically analyzed applying $F$ and T tests.

Results indicated that all ewes treated with vaginal sponges showed estrous and mated by the fertile rams, and estrous manifestation lasted for (3) consecutive days after sponges withdrawal. It was found that 35\%,55\%, and $10 \%$ of the ewes showed estrous in days 1, 2 and 3, respectively. It was also found that $85 \%$ of ewes joined with the fertile rams lambed, out of which $62.5 \%$ and $22.5 \%$ lambed to mating at first and second estruses.

Overall lambing rate was $114.7 \%$ and the percentages of ewes giving birth to singles and multiples were $88.2 \%$ and $11.8 \%$, respectively. The results also showed that there were no significant effects of body weight and age of ewes on pregnancy length and lamb birth weight $(P<0.05)$. Average live weight of male lambs was found to be heavier at birth in comparison with female lambs $(P<0.05)$. The male lambs were heavier at birth by $20 \% 12 \%$ and $17 \%$ than females in single, twin and multiple births, respectively.

Keywords: Awassi ewes, estrous Synchronization, twining rate 
دراسة حول استجابة نعاج العواس للمعاملة الهرمونية خلال موسم التناسل الطبيعي أحمد غسان غادرى قسم الإنتاج الحيوانس، كلية الزراعة، جامعة طب، طب، سوريا

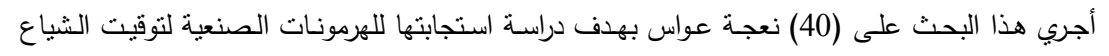

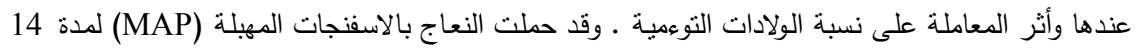

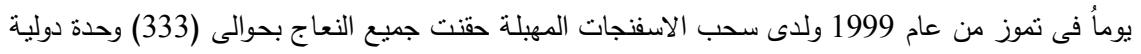

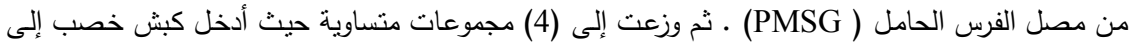

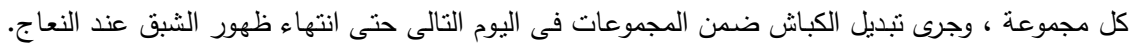

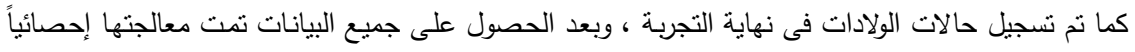

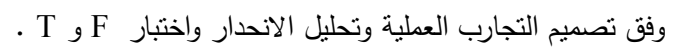

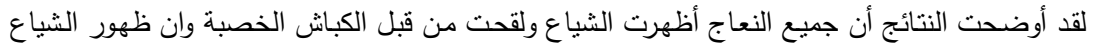

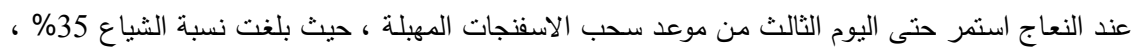

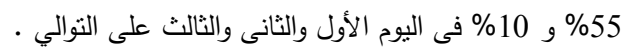

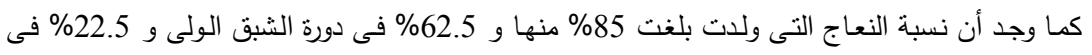

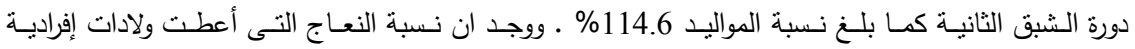

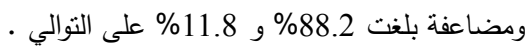

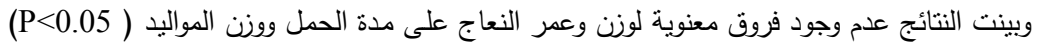

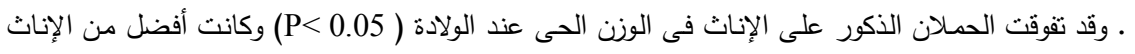

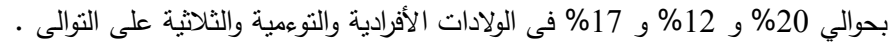

